\section{Effect of Finish Line on Marginal Fit of Sintered Gold Copings}

Fernanda Pelogia Gwinner ${ }^{1}$, Marco Antonio Bottino², Lafayete NogueiraJunior ${ }^{2}$ Álvaro Della Bona ${ }^{3}$

The aim of this study was to evaluate the vertical marginal gap of sintered gold copings and metal-ceramic crowns with different finish line preparations: a beveled round shoulder (BRS) and a beveled long chamfer (BLC), testing the null hypotheses that there are no differences in marginal gap regardless of finish line and phase of restoration (coping or crown). Stainless steel master models were fabricated to simulate tooth preparation for metal-ceramic crowns with different finish lines (BRS and BLC). Ten dies were obtained from each model. Preparations were coated with 2 layers of spacer to $1 \mathrm{~mm}$ from the margin. Sintercast gold copings were prepared, sintered and adjusted to the dies. The copings $(n=10)$ were placed onto the master model and the marginal gap was measured in 24 equidistant points using optical microscopy (X230). An opaque and two body ceramic layers were subsequently applied to the copings and the same measuring procedure was performed for the crowns. The data were analyzed statistically using paired and unpaired Student's t-test $(\alpha=0.05)$. Mean marginal gap values $(\mu \mathrm{m})$ for the copings and crowns were, respectively: 113.6 and 117.1 for the BRS; and 58.2 and 74.3 for the BLC preparation. Significantly greater marginal gaps $(p=0.0307)$ were found for restorations with BRS than with BLC finish line, which also showed statistically significant differences in the gap size between coping and crown $(p=0.001)$. In conclusion, marginal gap is influenced by ceramic application on copings fabricated on BLC preparation, and greater marginal gaps were found for restorations with BRS finish line, rejecting the experimental null hypotheses.

\author{
'Department of Biomaterials \\ and Biomechanics, Oregon \\ Health and Science University, \\ Portland, Oregon, USA \\ ${ }^{2}$ Department of Dental Materials \\ and Prosthodontics, São José \\ dos Campos School of Dentistry, \\ UNESP - Univ Estadual Paulista, \\ São José dos Campos, SP, Brazil \\ ${ }^{3}$ Graduate Program in Dentistry, \\ School of Dentistry, University \\ of Passo Fundo, RS, Brazil
}

Correspondence: Prof. Dr. Álvaro Della Bona, Campus 1, BR285, km 171, Passo Fundo, RS, Brasil. Tel: +55-543316-8395. E-mail: dbona@upf.br

Key Words: sintered gold crowns, metal ceramic alloys, marginal adaptation, dental porcelain.

\section{Introduction}

Several materials and techniques have been launched on the market in an effort to make restoration imperceptible $(1,2)$. Recently, due to the advancement of ceramic technology, metal-free restorations were developed. However, the traditional metal-ceramic restorations still present the requirements of high strength, long survival in the oral environment and favorable aesthetics (3).

The quality of marginal fit is extremely important to the clinical success of restorative procedures. A marginal misfit can de considered acceptable when it is visually imperceptible or cannot be detected using a dental probe (4). The existence of marginal gaps promote a discontinuous junction, which facilitates the biofilm retention (5), causing inflammation of the adjacent tissues (6), degrading the cementing agent and allowing the passage of gingival fluids and bacteria to the tooth-restoration interface (7), thus leading to the appearance of caries (8) and irreversible inflammatory pulp lesions (9).

Metal crowns and restorative infrastructures are commonly made by the lost wax technique that involves a series of laboratory steps (10) that may cause distortions and degradations of the margins and require special attention (9) to obtain adequate marginal fit of restorations (7). In addition, the application and sintering of ceramic layers may produce marginal gap, which can be associated with the type of alloy and its oxidation, ceramic contraction, difference in the coefficient of thermal expansion between the alloy and ceramic, metal infrastructure design and type of finish line $(12,13)$.

Esthetic problems with metal-ceramic restorations are also related to the metal coping that affects the translucence of the crown by restricting light transmission and increasing its reflectivity. To overcome this problem, several reinforced ceramic crown systems have been introduced on the market, such as electro-deposited and composite alloys $\left(\right.$ Captek $^{\mathrm{T}}{ }^{\mathrm{M}}$ ), which reduce the metal infrastructure to a thin foil. Extremely thin metal copings allow for thicker ceramic layers improving esthetic appearance and maintaining fracture resistance (14).

The marginal gap of metal-ceramic crowns has been the focus of various investigations $(5,7,8,13-20)$. There are, in the literature, several methods of gap measurements $(5,7,8,12,14-20)$ and no agreement of which is the most accurate way. The measuring of marginal gap using light microscopy has been widely used $(8,15,17,21)$ with variation in the magnitude of the microscope and number of measurement per sample.

A new technology to fabricate gold copings aiming to eliminate laboratory phases has been introduced to the dental market (Sintercast Gold; Nobil Metal, Torino, Italy). This system uses pure gold dispersed on a wax thin plate for sintering, resulting in a coping of approximately $0.3 \mathrm{~mm}$ thickness. As there are no studies reporting on 
the marginal fit of copings and crowns using this system (Sintercast Gold), the purpose of this study was to examine the vertical marginal gap of the gold copings and the resulting metal-ceramic restorations (crowns), comparing two types of cervical finish lines: a beveled round shoulder (BRS) and a beveled long chamfer (BLC), testing the null hypotheses that there are no differences in the marginal gap between the finish lines and between copings and resulted crowns.

\section{Material and Methods}

Two stainless steel master models with BRS and BLC cervical finish lines were fabricated (Fig. 1). An occlusal key groove was prepared for correct sitting of the copings and facilitate measurements.

Polyvinylsiloxane impressions (Elite; Zhermack S.p.A., Badia Polesine, Rovigo, Italy) using the double impression technique were taken according to the manufacturer's instructions. Ten dies from each master model were made using vacuum mixed type IV plaster (Elite Rock Thixotropic; Zhermack S.p.A.) following the manufacturer's instructions. The die preparations received two layers of a yellow die spacer ( $7 \mu \mathrm{m}$; Yeti Dental Produkte $\mathrm{GmbH}$, Engen, Germany) up to $1 \mathrm{~mm}$ before the margin (19).

The Sintercast Gold system (Nobil Metal) was used to fabricate the copings $(n=10)$. An aluminum foil was adapted around the preparation and served as a mold to prepare the Sintercast Gold foil. The Sintercast Gold was gently adapted around the cast and the excess was removed 1 $\mathrm{mm}$ below the gingival margin. The investment (RDM, Nobil Metal, Rovigo, Italy) was mixed and the coping was totally embedded in the investment and let it set before placing
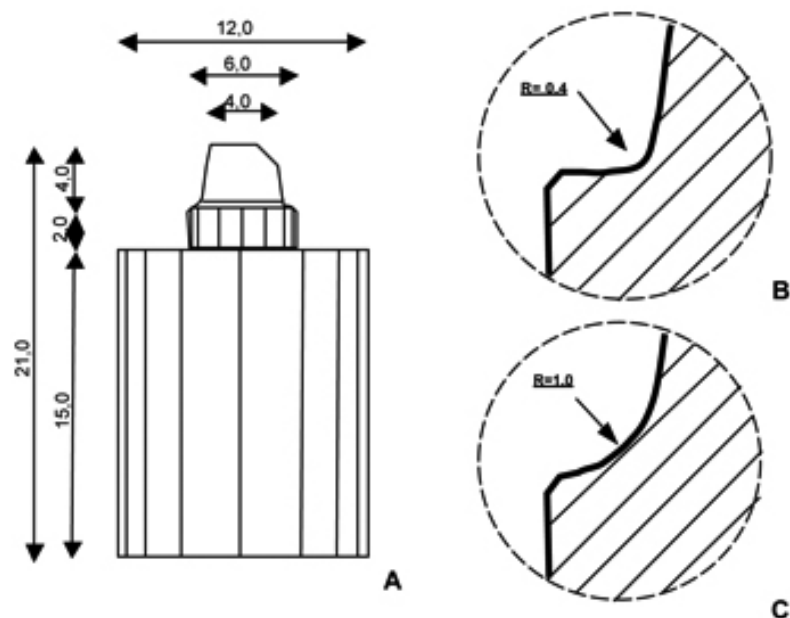

Figure 1. A: Schematic drawing of the stainless steel model and distance measurements (mm). B: Close-up view of the beveled rounded shoulder (BRS) finish line. C: Close-up view of the beveled long chamfer (BLC) finish line. it in a furnace (Compact 100 , Ugin, France) at $300^{\circ} \mathrm{C}$ as the initial temperature. The furnace temperature increased $70^{\circ} \mathrm{C} / \mathrm{min}$ up to $1030^{\circ} \mathrm{C}$, keeping it for $4 \mathrm{~min}$. The sintered coping was gently removed from the investment and replaced over the stone cast for final adjustments gently done with a rounded end metal instrument.

The copings were placed onto the master models. A metal apparatus was used for stabilization and application of constant pressure during the entire measuring process. Vertical marginal gap measurements were performed using 24 equidistant points determined by laser markings located $1 \mathrm{~mm}$ below the cervical finish line. An optical microscope coupled to a high-resolution digital color camera and 6.5:1 precision zoom optics (ROY-RAM Optical Instrumentation, Rochester, NY, USA) was used to perform the measurements. Therefore, 24 readings were recorded per sample and the greatest gap value was taken for each coping $(n=10)$.

An opaque ceramic layer (shade A2; Vintage Halo, Shofu Kyoto, Japan) and two 2-mm thick body ceramic layers (shade A2; Vintage Halo) were applied and fired to all gold copings, according to the manufacturer's instructions. The marginal gap of the metal-ceramic crowns was measured and recorded as described for the copings.

Data were analyzed statistically using the Student's t-test for paired and non-paired data at a significance level of $5 \%$.

\section{Results}

Twenty-four measurements were recorded for each coping and resulted metal-ceramic crown and only the greatest marginal gap value per specimen was registered and considered for statistical purposes. The mean greatest marginal values and statistical groupings are presented in Table 1.

The effect of the restoration fabrication phase (A before and B - after ceramic application) was analyzed using paired $t$ tests and the effect of the finish line (BRS $x B L C)$ was analyzed using independent $t$ test. There was

Table 1. The mean greatest marginal gap (in $\mathrm{mm}$ ) and standard deviation (S.D.) values showed for the copings (A) and the final metal-ceramic crowns (B) fabricated using preparations with beveled round shoulder (BRS) and beveled long chamfer (BLC) finish lines

\begin{tabular}{ll}
\hline Group $(\mathrm{n}=10)$ & Mean (S.D.) \\
\hline BRS-A & $113.6(47.5)^{\mathrm{a}}$ \\
BRS-B & $117.1(49.1)^{\mathrm{a}}$ \\
BLC-A & $58.2(20.5)^{\mathrm{c}}$ \\
BLC-B & $74.3(24.6)^{\mathrm{b}}$ \\
\hline
\end{tabular}

Different letters indicate statistically significant difference $(p<0.05)$ between A and B within same type of finish line. 
a significant difference between BLC-A and BLC-B, where the coping showed better marginal fit than the crown $(p=0.001)$. No significant differences were found between BRS-A and BRS-B $(p=0.065)$. Overall, there was a significant difference on the type of finish line, where the BLC showed better marginal fit than the BRS $(p=0.0307)$.

\section{Discussion}

When a full veneer crown restoration is placed in a healthy environment, the maintenance of this health apparently depends on the marginal integrity, crown contour, oral hygiene and the patient's intrinsic resistance to disease (22). There is consensus in the literature that there is still no dental restorative system on the market, capable of providing restorations with perfect, gap-free fit $(5,21)$. In the oral environment, dental cements are invariably immersed in an aqueous solution. In this environment, the cement layer close to the margin may dissolve, forming a rough surface propitious for plaque retention (22) and bacterial infiltration. Therefore, a number of studies are conducted with the intention of obtaining materials that present lower levels of marginal gap, providing better tooth/restoration interface sealing, with reduced thickness of exposed luting cement.

A well-fitting crown reduces the chance for recurrent caries and periodontal disease, whereas the space between a poorly fitted artificial crown and tooth preparation enables accumulation of bacterial plaque (5).

The technique developed by the Italian industry NobilMetal and used in the present study to make the copings, aims at eliminating some of the laboratory stages, thereby reducing the manufacturing time and marginal fit. With this technique, there is no need to do infrastructure waxing, inclusion in refractory coating, casting and alloy injection.

The copings obtained by this technique are composed of 99.9\% gold, the most precious of metals used in dentistry, rarely becoming stained or corroded in the oral cavity. It is the most ductile of metals and also the most malleable (23). This characteristic facilitates margin burnishing to obtain a clinically precise fit.

In the present study, two types of finish line were used, the long chamfer and the rounded shoulder, with $1 \mathrm{~mm}$ of axial surface reduction at the margin; both with a 0.5 $\mathrm{mm}$ bevel and angulation of $45^{\circ}$. Gilboe and Thayler (24) related that the cervical bevel eliminates the possibility of leaving a poorly supported or weak enamel margin and will establish an obtuse angle of tooth structure for strength. The resulting acute angle of malleable gold alloy can be readily finished without danger to the enamel margin.

The manufacture of metal-ceramics crowns by the technique of lost-wax casting involves a series of laboratories steps (infrastructure waxing, inclusion, wax elimination, metal alloy casting, finishing and polishing) that negatively affect the prosthetic restorations sealing when compared with the electroformed crowns, as observed by Holmes et al (19).

The infrastructure confection system used in this study eliminates important laboratory steps used in the conventional techniques, such as waxing, inclusion, wax elimination and casting. The infrastructure confection technique by electrodeposition of gold on the die also aims to eliminate laboratory steps, but requires special appliances (20).

The yellow color of the metal minimizes the technical difficulties because the ceramist does not have to mask the grayish color of the metal, thus guaranteeing an important esthetic advantage to the final work.

The reduced metal thickness $(0.3 \mathrm{~mm})$ also helps on the esthetic appearance, since it enables a thicker ceramic layer. This reduction of coping thickness has a negligible effect on the stress levels in the porcelain.

In some cases, a well-fitted metal coping may not fit after porcelain application (15). Some authors believe that the most significant change occurs during the alloy oxidation cycle (16).

In this study, there was no significant difference in marginal gap before and after ceramic application on restorations fabricated on BRS preparation. This finding is in agreement with previous studies $(12,15,17,20)$. However, other studies $(13,18)$ have reported that the marginal gap increased significantly after ceramic application.

The ceramic chosen for the present study presented a linear thermal expansion coefficient between 13.8 and 15.2 $x 10^{-6}{ }^{\circ} \mathrm{C}$ as recommended by the manufacturer.

In this study, mean vertical marginal gap values of 74.3 $\mu \mathrm{m}$ and $117.1 \mu \mathrm{m}$ after ceramic application were obtained for BLC and BRS finish lines, respectively. The difference in fit between the finish lines may be associated with the restoration fabrication technique. As great caution is necessary while modeling a coping, in order not to change the gold lamina thickness, the chamfered preparation possibly facilitates this application.

Although statistically significant differences occurred between the types of finish lines used in present study, all the results were found to be safely within the clinically acceptable standards. McLean and Von Fraunhofer (25), in a clinical study of 100 restorations in a 5-year period concluded that $120 \mu \mathrm{m}$ represents the maximum clinically acceptable misfit.

Although no exact prediction can be made about the clinical longevity of metal-ceramic restorations, based only on laboratory data, the results of the present study suggest that metal-ceramic crowns fabricated using pure sintered gold infrastructure produce clinically acceptable 
marginal fit with either type of finish line investigated (BLC and BRS), although the marginal gaps were smaller when using BLC preparations.

Within the limitations of this in vitro study, the results showed that the marginal gap is influenced by the ceramic application on copings fabricated on BLC preparation. In addition, greater marginal gaps were found for restorations with BRS than with BLC finish line, rejecting the experimental null hypotheses.

\section{Resumo}

0 objetivo deste estudo foi avaliar a fenda marginal vertical de copings de ouro sinterizado e coroas metalo-cerâmicas com diferentes tipos de término de preparo: ombro arredondado biselado $(\mathrm{OAB})$ e chanfro longo biselado (CLB), testando a hipótese nula de que não há diferenças na adaptação marginal quando se compara o tipo de término ou a fase da restauração (coping ou coroa). Modelos de aço inoxidável foram confeccionados simulando preparos dentais com diferentes términos (OAB e CLB). Dez modelos de gesso foram confeccionados a partir de cada preparo. Duas camadas de espaçador foram passadas em cada preparo, a $1 \mathrm{~mm}$ da margem. Os copings de Sintercast confeccionados, sinterizados e ajustados ao modelo de gesso. Os copings $(n=10)$ foram colocados no modelo de aço e a fenda marginal foi medida em 24 pontos equidistantes por meio de microscópio óptico (×230). Uma camada de opaco e duas de porcelana feldspática foram aplicadas sobre os copings e o mesmo processo de mensuração de fenda foi utilizado para as coroas. Os dados foram analisados estatisticamente usando o teste t Student pareado e não-pareado $(\alpha=0,05)$. Os valores médios de fenda marginal $(\mu \mathrm{m})$ para os copings e coroas foram, respectivamente: 113,6 e 117,1 para $O A B$; e 58,2 e 74,3 para CLB. Fendas marginais significantemente maiores $(p=0,0307)$ foram observadas nas restaurações com términos $O A B$ quando comparados ao término $C L B$, o qual mostrou diferenças estatísticas na comparação entre coping e coroa $(p=0,001)$. Em conclusão, a fenda marginal é influenciada pela aplicação de cerâmica em copings fabricados com términos CLB, e fendas marginais maiores foram observadas para restaurações com término $O A B$, rejeitando-se as hipóteses nulas.

\section{Acknowledgements}

This research project was supported by CAPES and Labordental.

\section{References}

1. Cho L, Song H, Koak J, Heo S. Marginal accuracy and fracture strength of ceromer/fiber-reiforced composite crowns: effect of variations in preparation design. J Prosthet Dent 2002;88:388-395.

2. Quintas AF, Oliveira $F$, Bottino MA. Vertical marginal discrepancy of ceramic copings with different ceramic materials, finish lines and luting agents: an in vitro evaluation. J Prosthet Dent 2004;92:250-257.

3. Silva GR, Roscoe MG, Ribeiro CP, Mota, AS, Martins LRM, Soares CJ. Impact of rehabilitation with metal-ceramic restorations on oral health-related quality of life. Braz Dent J 2012;23:403-408.

4. Colpani JT, Borba M, Della Bona A. Evaluation of marginal and internal fit of ceramic crown copings. Dent Mater 2013:29:174-180.

5. Abbate MF, Tjan AHL, Fox WM. Comparison of the marginal fit of various ceramic crown systems. J Prosthet Dent 1989;61:527-531.

6. Shafagh I. Plaque accumulation on cast gold complete crowns polished by a conventional and an experimental method. J Prosthet Dent 1986;55:399-342.

7. Harris IE, Wickens JL. A comparison on the fit of spark-eroded titanium copings and cast gold alloy copings. Int J Prosthod 1994;7:348-354.

8. Groten M, Girthofer S, Probster L. Marginal fit consistency of copymilled all-ceramic crowns during fabrication by light and scanning electron microscopic analysis in vitro. J Oral Rehabit 1997;24:871-881.

9. Kydd WD, Nicholls Jl, Harrington G, Freeman M. Marginal leakage of cast gold crowns luted with zinc phosphate cement: an in vivo study. J Prosthet Dent 1996;75:9-13.

10. Eames WB. The casting misfit: How to cope. J Prosthet Dent $1981 ; 45 ; 283-285$.

11. Hunter AJ, Hunter AR. Gingival crown margin configurations: a review and discussion. Part I: terminology and widths. J Prosthet Dent 1990;64:548-552.

12. Castellani D, Bacetti T, Clauser C, Bernardini UD. Thermal distortion on different material in crown construction. J Prosthet Dent 1994;72:360366.

13. Campbell SD, Sirakian A, Pelletier LB, Giordano RA. Effects of firing cycle and surface finishing on distortion of metal ceramic castings. J Prosthet Dent 1995;74:476-481.

14. Pettenó D, Schierano G, Bassi F, Bresciano ME, Carossa S. Comparison of marginal fit of 3 different metal-ceramic systems: an in vitro study. Int J Prosthodont 2000;13:405-408.

15. Shillingburg HT, Hobo S, Fisher DW. Preparation design and margin distortion in porcelain-fused-to-metal restorations. J Prosthet Dent 1973;29:276-284.

16. Anusavice KJ, Carroll JE. Effect of incompatibility stress on the fit of metal-ceramic crowns. J Dent Res 1987;66:1341-1345.

17. Leong D, Chai J, Lautenschlager E, Gilbert J. ONG, D. et al. Marginal fit of machine-milled titanium and cast titanium single crowns. Int J Prosthodont 1994;7:440-447.

18. Gemalmaz D, Alkumuru HN. Marginal fit changes during porcelain firing cycles. J Prosthet Dent 1995;73:49-54.

19. Holmes J, Richer ES, Rivers JA, Stewart RM. Marginal fit of electroformed ceramometal crowns. J Prosthodont 1996;5:111-114.

20. Buso L, Hilgert $E_{1}$ Neisser MP, Bottino MA. Marginal fit of electroformed copings before and after the coction of the porcelain. Bras J Oral Sci 2004;3:409-413.

21. Sorensen JA. A rationale for comparison of plaque-retaining properties of crown systems. J Prosthet Dent 1989;62:264-269.

22. Koth DL. Full crown restorations and gingival inflammation in a controlled population. J Prosthet Dent 1982;48:681-685.

23. Anusavice KJ. Phillips Science of Dental Materials. 11th ed. Elsevier; 2003. p. 533-83.

24. Gilboe DB, Thayer KE. Bevelled shoulder concept: full gold crown preparation. J Can Dent Assoc 1980;46:519-523.

25. McLean JW, Fraunhofer JA. The estimation of cement film thickness by an in vivo technique. Br Dent J 1971;131:107-111. 